\title{
PELATIHAN PEMBUATAN MEDIA PEMBELAJARAN MENGGUNAKAN POWERPOINT SCREEN RECORDING BAGI GURU DI SMP KESATRIAN 2 SEMARANG
}

\author{
Iryan Dwi Handayani1), Seno Suharyo ${ }^{1)}$, Diah Aryati Puji Lestari1) \\ 1)Program Studi Teknik Sipil, Fakultas Teknik, Universitas Semarang, Jawa Tengah, Indonesia \\ Corresponding author : Iryan Dwi Handayani \\ E-mail : iryandwi1201@gmail.com
}

Diterima 29 November 2021, Direvisi 03 Desember 2021, Disetujui 03 Desember 2021

\begin{abstract}
ABSTRAK
Pandemi covid 19 memang membawa dampak yang sangat besar bagi dunia dan bagi bangsa Indonesia pada khususnya. Dunia pendidikan yang biasanya bisa bertemu tatap muka antara siswa dan guru atauu mahasiswa dengan dosen, karena pandemi maka pembelajaran dilaksanakan secara online atau pembelajaran jarak jauh. Tantangan yang dihadapi oleh para pendidik di era pandemi ini adalah bagaimana harus merevisi dan merubah media pembelajaran dan strategi pembelajaran yang harus dibuat supaya siswa bisa memahami materi yang diberikan. Powerpoint merupakan salah satu bagian dari software Microsoft office yang biasa digunakan untuk membuat presentasi ataupun media pembelajaran. Tujuan dari kegiatan ini untuk meningkatkan pengetahuan dan pelatihan tentang pemanfaatan powerpoint screen recording. Metode pelaksanaan pengabdian ini yaitu identifikasi permasalahan, pendekatan penyelesaian masalah dan hasilnya 40 peserta akan menggunakan manfaat dari pelatihan untuk proses belajar mengajar di sekolah, dan 42 peserta menyatkan bahwa pelatihan tersebut sangat bermanfaat dalam proses kegiatan pembelajaran.
\end{abstract}

Kata kunci: powerpoint screen recording; PJJ

\begin{abstract}
The COVID-19 pandemic has had a huge impact on the world and the Indonesian people in particular. The world of education is usually able to meet face-to-face between students and teachers or students and lecturers, because of the pandemic, learning is carried out online or distance learning. The challenge faced by educators in this pandemic era is how to revise and change learning media and learning strategies that must be made so that students can understand the material provided. Powerpoint is one part of Microsoft office software which is commonly used to make presentations or learning media. The purpose of this activity is to increase knowledge and training on the use of powerpoint screen recording. The method of implementing this service is problem identification, problem solving approach and the result is that 40 participants will use the benefits of the training for the teaching and learning process in schools, and 42 participants stated that the training was very useful in the process of learning activities.
\end{abstract}

Keywords: powerpoint screen recording; PJJ

\section{PENDAHULUAN}

Pandemi covid 19 telah membuat Indonesia dan seluruh dunia beralih dari sistem pembelajaran tatap muka ke sistem pembelajaran online(Andiani \& Fitria, 2021). Semua bidang terdampak karena adanya pandemi ini, bidang kesehatan, ekonomi, pembangunan dan pendidikan. Dunia pendidikan yang biasanya bisa bertemu tatap muka antara siswa dan guru atauu mahasiswa dengan dosen, karena pandemi maka pembelajaran dilaksanakan secara online atau pembelajaran jarak jauh. Tetapi tidak mudah melaksanakan pembelajaran secara online, guru harus pandai-pandai memilih metode dan media pembelajaran untuk bisa memacu semangat belajar siswa.

Tantangan yang dihadapi oleh para pendidik di era pandemi ini adalah bagaimana harus merevisi dan merubah media pembelajaran dan strategi pembelajaran yang harus dibuat supaya siswa bisa memahami materi yang diberikan. Selain itu kendala yang dihadapi adalah untuk membuat media tersebut dibutuhkan kuota internet dan pelatihan bagi guru, untuk bisa mengikuti pelatihan secara online pun harus mempunyai kuota internet yang kuat. Di tengah pandemi Covid-19 ini, sistem pendidikan kita harus siap melakukan lompatan untuk melakukan transformasi pembelajaran daring bagi semua siswa dan 
oleh semua guru. Kita memasuki era baru untuk membangun kreatifitas, mengasah skill siswa, dan peningkatan kualitas diri dengan perubahan sistem, cara pandang dan pola interaksi kita dengan teknologi (Suharwoto, 2020). Administrasi yang dipersiapkan juga harus mengacu pada pembelajaran sistem jarak jauh atau PJJ. Perubahan diawali dari RPP, penilaian dan media pembelajaran yang akan digunakan. Adaptasi teknologi sangat dibutuhkan untuk bisa menunjang terlaksananya pembelajaran online ini, dari hal ini dituntut juga peningkatan litearsi digital akan meningkat.

Pemerintah pusat telah menyediakan berbagai macam aplikasi yang bisa digunakan baik oleh siswa ataupun guru secara gratis. Selain itu ada pembelajaran di TVRI yang bisa dilihat siswa di setiap pagi hari, ada juga sebuh aplikasi yang sebenarnya berbayar, tetapi karena pandemi seperti ini dibuka gratis untuk siswa SD sampai SMA. Pemerintah juga memberikan dana pendidikan BOS (Bantuan Operasional Siswa) untuk memenuhi kebutuhan kuota bagi guru dan siswa.

Aplikasi pembelajaran online juga sudah disediakan pemerintah secara gratis, contohnya ada rumah belajar, kipin school 4.0, meja kita, google for education, brainly Indonesia, zenius dan cisco webex.

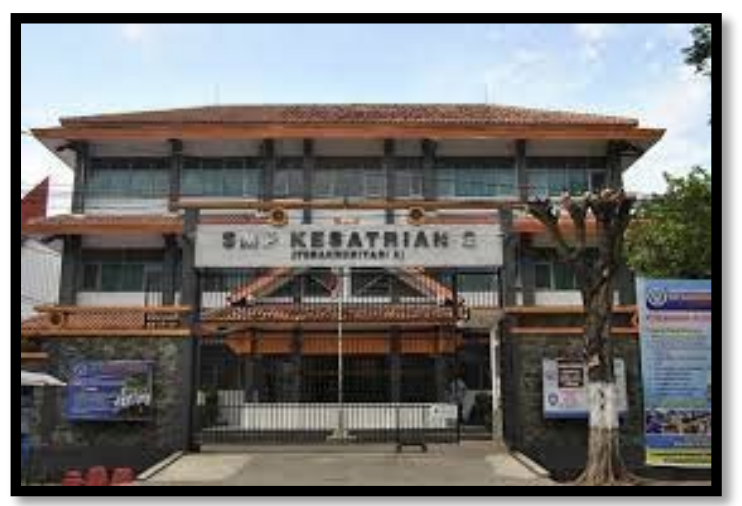

Gambar 1. SMP Kesatrian 2 Semarang

SMP Kesatrian 2 Semarang terletak di JI. Pamularsih no.96 Semarang. Karena setiap guru dan siswa sekarang sudah memiliki laptop ataupun hp yang bisa digunakan untuk melaksanakan pembelaaran secara online, maka untuk melaksanakan pembelajaran online sudah tidak terkendala lagi. Akan tetapi kendalanya guru di SMP Kesatrian 2 hanya menggunakan google classroom saja, sehingga siswa masih cenderung malas untuk membaca. Hanya powerpoint yang bentuknya slide saja yang diberikan untuk siswa. Penggunaan media pembelajaran yang tepat dapat membantu meningkatkan pemahaman anak didik terhadap materi yang disampaikan oleh guru. Salah satunya adalah media Powerpoint, yang akan membantu siswa memahami materi yang disampaikan oleh guru (Amalia, 2014).

Pemanfaatan Powerpoint screen recording untuk pembuatan media pembelajaran

Powerpoint merupakan salah satu bagian dari software Microsoft office yang biasa digunakan untuk membuat presentasi ataupun media pembelajaran. Fasilitas yang disediakan powerpoint sangalah beragam, tidak hanya slide saja melainkan bisa digunakan untuk merekam salam bentuk video. Pembelajaran dengan memanfaatkan powerpoint meningkatkan motivasi belajar siswa yang signifikan, perbedaan peningkatan motivasi belajar siswa antara kelas kontrol dengan kelas yang menggunakan powerpoint adalah bahwa kelas eksperimen memiliki motivasi yang lebih tinggi daripada yang tidak meggunakan powerpoint (Cucum и съавт., 2018).

Powerpoint banyak digunakan karena pengoperasiannya yang mudah dan semua orang mampu untuk membuat powerpoint, banyak fitur yang menarik seperti kemapuan pengolah teks, menyimpan gambar, audio dan animas yang dapat diatur sesuai selera pengguna (Misbahudin и съавт., 2018). Media pembelajaran powerpoint ini juga memudahkan siswa dalam pembelajaran jarak jauh di masa pandemi COVID 19 karen sifatnya praktis, mudah digunakan, memiliki ukuran file yang kecil dan tidak memerlukan banyak kuota untuk mengaksesnya (Purwanti и съавт., 2020).

Permasalahannya adalah bahwa guru di SMP Kesatrian 2 Semarang masih memberikan materi power point yang berupa slide saja, tanpa ada penjelasan dari rekaman screen recorder. Tujuan dari kegiatan ini adalah memberikan pengetahuan dan pelatihan tentang pemanfaatan powerpoint screen recorder.

\section{METODE}

Metode yang akan dilaksanakan dalam mengatasi permasalahan yang dihadapi adalah sebagai berikut:

\section{Identifikasi Permasalahan}

Tahapan ini dilakukan dengan melakukan survei ke SMP Kesatrian 2 Semarang, melakukan wawancara dengan guru dan kepala sekolah didapatkan bahwa guru di SMP Kesatrian 2 ini hanya memanfaatkan powerpoint yang berupa slide saja. Artinya para guru masih hanya tertuju 1 arah saja pembelajarannya. Siswa SMP pada jaman seperti ini sudah banyak yang memiliki HP ataupun laptop, sehingga mereka bisa membuka video penjelasan dari slide yang diberikan. 


\section{Pendekatan Penyelesaian Masalah}

Salah satu penyelesaian masalah yang dihadapi adalah dengan memberikan pelatihan kepada guru-guru tentang pembuatan powerpoint screen recording sebagai media pembelajaran. Sebelum pelatihan diadakan pretest terlebih dahulu. Gambaran pendekatan penyelesaian masalahnya sebagai berikut :

a) Pelaksana : Tim Pelaksana Pengabdian Universitas Semarang dan mahasiswa

b) Peserta : 50 Guru SMP Kesatrian 2 Semarang .

c) Lokasi : Ruang guru atau ruang komputer. Pelaksanaan pelatihan dibantu oleh mahasiswa dalam membuat powerpoint screen recording.

\section{HASIL DAN PEMBAHASAN}

\section{Analisa Hasil}

Berdasarkan evaluasi dari tiap sesi yang diberikan, berikut adalah hasil evaluasinya :

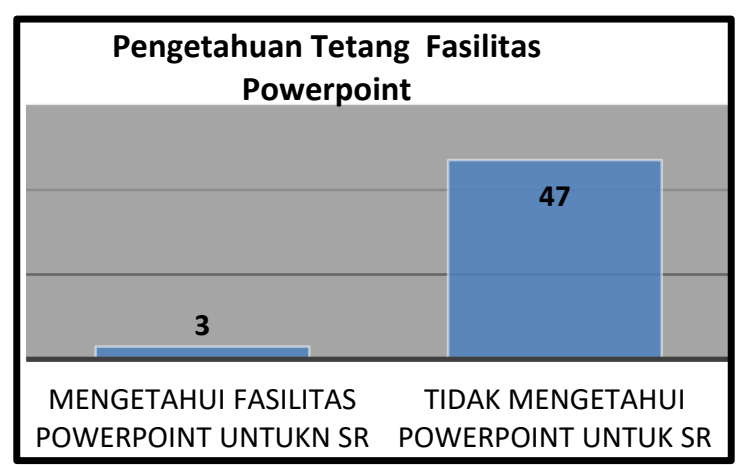

Gambar 2. Grafik tentang pengetahuan fasilitas powerpoint

Kuisioner 1 diberikan sebelum pelatihan dimulai, pada hasil kuisioner ini dari 50 peserta pelatihan, 47 tidak mengetahui bahwa di powerpoint bisa digunakan untuk merecord layar yang ada di monitor selain PPT dan 3 peserta sudah mengetahui adanya fasilitas tersebut.

Peserta pelatihan juga masih banyak yang belum mengetahui semua fitur yang ada di dalam powerpoint. Sebanyak 6 peserta pelatihan mengetahui semua fungsi fitur yang ada di powerpoint, sedangalkan ada 44 peserta hanya mengetahui sebagian fitur yang ada di powerpoint beserta dengan fungsinya, seperti yang terlihat pada gambar 3 .

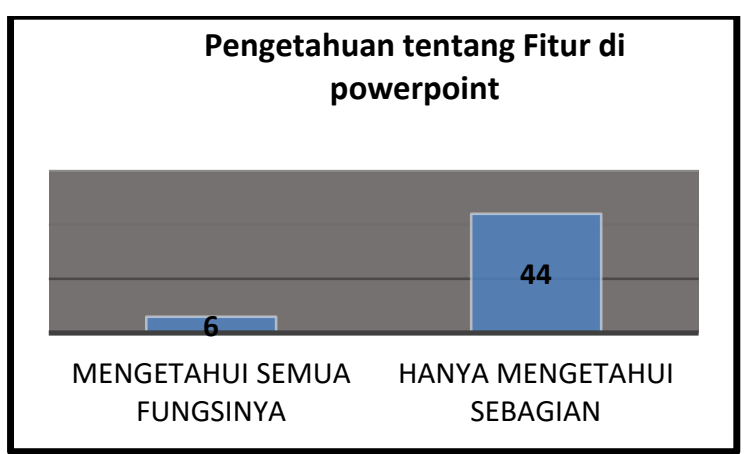

Gambar 3. Grafik tentang pengetahuan fitur di powerpoint

Setelah pelatihan berlangsung, peserta juga mengisi kuisioner tentang fungsi pelatihan yang diberikan dan kelanjutan peserta dalam menggunakan powerpoint screen recording. Sebanyak 42 peserta menyatakan bahwa pelatihan tentang powerpoint screen recording sangat membantu nantinya dalam pembuatan media pembelajaran di situasi pandemi seperti ini, sedangkan 8 peserta menyatakan tidak membantu dalam pembuatan recording layar atau screen recording. Grafiknya seperti terlihat di gambar 4.

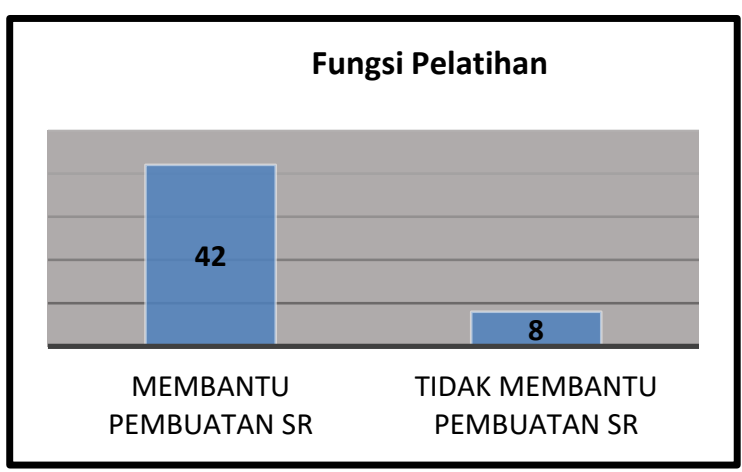

Gambar 4. Grafik tentang fungsi pelatihan

Kuisioner ke 4 tentang bagaimana kelanjutan dalam menggunakan hasil dari pelatihan tentang powerpoint screen recording, 10 peserta pelatihan belum pasti akan menggunakannya, dan 40 peserta akan menggunakan fasilitas tersebut dalam pembuatan media pembelajaran.

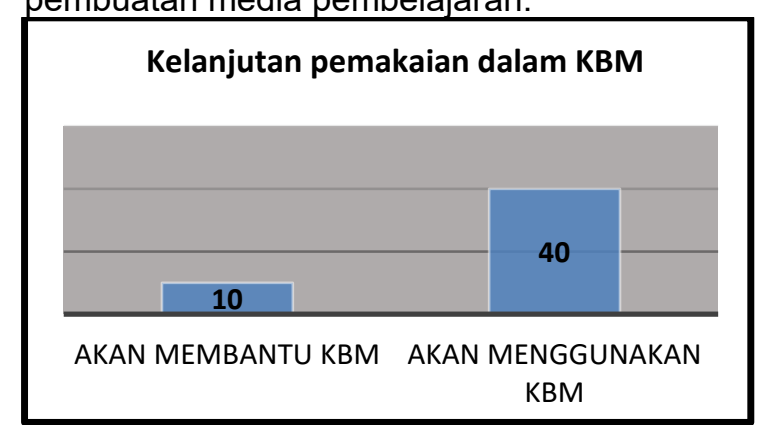

Gambar 5. Grafik Tentang Pemakaian dalam KBM 


\section{Evaluasi Kegiatan}

Evaluasi pada saat kegiatan berlangsung antara lain peserta sudah bisa menggunakan dan memanfaatkan fasilitas screen recording yang ada di powerpoint. Sebagian besar sudah mencoba membuat rekaman dari materi pelajaran yang diampu oleh masing-masing guru, tetapi kendala yang ada adalah peserta belum bisa maksimal memasukkan suara di dalam rekaman tersebut, dikarenakan fasilitas yang ada di laboratorium komputer tidak ada microphone. Kegiatan selama pelatihan didokumentasikan seperti gambar 6.

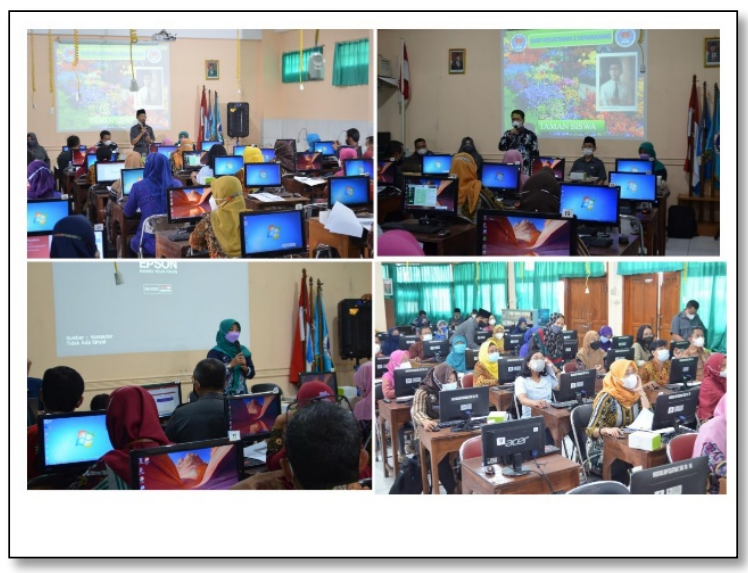

Gambar 6. Kegiatan pelatihan Powerpoint screen recording

\section{SIMPULAN DAN SARAN}

Simpulan dari pelatihan ini adalah bahwa pelatihan powerpoint screen recording diberikan kepada guru-guru di SMP Kesatrian 2 Semarang, peserta mendapatakan pelatihan tersebut sehingga dapat memanfaatkannya untuk mengembangkan pembuatan media pembelajaran di masa pandemi. 40 peserta akan menggunakan manfaat dari pelatihan untuk proses belajar mengajar di sekolah, dan 42 peserta menyatkan bahwa pelatihan tersebut sangat bermanfaat dalam proses kegiatan pembelajaran.

Saran dari kegiatan ini bahwa kegiatan belajar mengajar di masa pandemi seperti harus dilakukan dengan variatif dan inovatif, sehingga bisa menarik minat siswa untuk belajar secara mandiri di rumah. Diperlukan kegiatan pendampingan dalam pelatihan secara berkelanjutan.

\section{UCAPAN TERIMAKASIH}

Penulis mengucapkan terimaksih kepada Universitas Semarang dan LPPM Universitas Semarang, yang telah memfasilitasi kegiatan pengabdian kepada masyarakat ini dapat terealisasi.

\section{DAFTAR RUJUKAN}

Amalia, I. A. (2014). Power Point Sebagai Alternatif Media Pembelajaran Masa Kini. Jurnal Edueksos, III(2), 127-144.

Andiani, W., \& Fitria, H. (2021). Pembelajaran Daring Menggunakan Media Online Selama Pandemi Covid-19 Pada Siswa Sd Negeri 103. Prosiding Seminar Nasional Pendidikan Program Pascasarjana Universitas PGRI Palembang, 172-181.

Cucum, Rohayat, A., Rusmana, M., \& Tetep. (2018). Penggunaan Media Pembelajaran Program Powerpoint Terhadap Motivasi Dan Hasil Belajar Siswa Pada Pelajaran IPA Sekolah Dasar. Jurnal Teknologi Pendidikan dan Pengembangan, 3(1), 418-440.

https://journal.institutpendidikan.ac.id/ind ex.php/tekp/article/view/142/217

Misbahudin, D., Rochman, C., Nasrudin, D., \& Solihati, I. (2018). Penggunaan Power Point Sebagai Media Pembelajaran: Efektifkah? WaPFi (Wahana Pendidikan Fisika), 3(1), 43. https://doi.org/10.17509/wapfi.v3i1.10939

Purwanti, L., Widyaningrum, R., \& Melinda, S. A. (2020). Analisis Penggunaan Media Power Point dalam Pembelajaran Jarak Jauh pada Materi Animalia Kelas VIII. Journal Of Biology Education, 3(2), 157. https://doi.org/10.21043/jobe.v3i2.8446

Suharwoto, G. (2020). No Title. https://pusdatin.kemdikbud.go.id/pembela jaran-online-di-tengah-pandemi-covid-19tantangan-yang-mendewasakan/ 